\title{
Proximate composition and mineral content of the Fresh water snail (Pila ampullacea) from River Benue, Nigeria.
}

\author{
${ }^{1}$ R. A. Obande, ${ }^{2}$ S. Omeji and ${ }^{3}$ I. Isiguzo \\ ${ }^{1,2,3}$ Department of Fisheries and Aquaculture, University of Agriculture, P.M.B.2373, Makurdi, Benue State, \\ Nigeria.
}

\begin{abstract}
The nutritional composition and mineral contents of the fresh water snail (Pila ampullacea) from Lower River Benue was investigated. This was carried out using the methods outline in Association for Official Analytical Chemist (A.O.A.C. 1995) in the Vertinary Research Institute Vom, Plateau State, Nigeria. The results obtained showed that the snail contained $76.32 \% \pm 0.84$ moisture, $10.67 \% \pm 0.15$ protein, $0.06 \% \pm 0.02$ lipids, $5.54 \% \pm 0.11$ ash, $0.03 \% \pm 0.01$ crude fiber and $7.40 \% \pm 0.06$ Nitrogen free extract. The following minerals were found to be present in the snail. These were calcium $129.18 \pm 0.77 \mathrm{mg} / 100 \mathrm{~g}$, potassium $71.13 \pm 0.51 \mathrm{mg} / 100 \mathrm{~g}$, phosphorous $60.52 \pm 0.35 \mathrm{mg} / 100 \mathrm{~g}$, iron $10.19 \pm 0.19$, sodium $0.04 \pm 0.01 \mathrm{mg} / 100 \mathrm{~g}$, magnesium $31.19 \pm$ $0.57 \mathrm{mg} / 100 \mathrm{~g}$ and zinc $1.31 \pm 0.03 \mathrm{mg} / 100 \mathrm{~g}$. This study therefore places $P$. ampullacea as a good source of major and micro- elements and a good source of healthy food for proper growth and development of the body. Its production either from the wild or cultured environment could be a good source of income for the teaming population.
\end{abstract}

Key words: P. ampullacea, nutritional values, mineral composition, income generation.

\section{Introduction}

Shellfishes comprise of invertebrate animals called Crustaceans such as shrimps, crabs, lobsters, crayfish and molluscs such as bivalves, squids and clams. Molluscs posses exoskeleton called shells which may be single or double over the body. Most of them are marine, although there are fresh water forms. In West Africa, there is abundance of shellfishes in the waters (Okon, 1987). The inshore fish resources of Nigerian waters include demersal and pelegic shellfish resources. The potential yield from inshore waters is estimated at 201, 000 metric tonnes per- annum (Adetayo, 1986). There has been a lot of investigation into the proximate composition and fatty acid contents of food items (Luzai, et al,. 2003). Aquatic animals contain high levels of protein (17-20\%) with an amino acid profile similar to that of meat from land animals, thus making it beneficial to health in Countries where there is high consumption of fished shellfishes.

One of the greatest problems facing the world today is that of providing sufficient food of adequate quality for its teaming population. The food deficit situation is more intense with protein and mineral deficiencies (Adesihinwa and Ogunowmodede, 1995). In a typical Nigerian village, the immediate show of malnutrition is manifested by the number of children and the aged with kwashiorkor (Idufweke, 1984). There is therefore the need to find a way of raising the protein intake of the average Nigerian from $5.5 \mathrm{~g} / \mathrm{head} / \mathrm{day}$ (FAO, 1988) to $35 \mathrm{~g} / \mathrm{head} /$ day (Idufweke, 1994). This can be achieved by widening the scope of livestock research to commercial snail farming either from the wild or cultured species which can generate enough protein sources for the family.

Pila is a genius of large water snails, an aquatic gastropod mollusc of the family Ampullariidae. In West Africa and Europe the widely consumed families are the Helicidae and Achantinidae (Hodasi, 1982) which are land snails. However, in West Africa and Asia, large water snails like pila species are quite a delicacy in some riverine areas.

Fish and shellfishes have been found to be a major source of protein to both riverine and the general population at large, as they occur abundantly in the brackish and fresh waters (Tayo et al,. 2008). They have also being found to be good source of protein, low in fat and calories making a very healthy choice of food (Falode, 2009). The different species of these shellfishes are periwinkles (Tympanotomus spp), oysters, prawns, snails and clams. The fresh water snails commonly harvested by the artisanal fishers are Lanistes spp, Nucella spp, Bulinus and Pila. Although, it has been found that shellfishes have high cholesterol, it is low in saturated fat which is not dangerous to human health. The land snail Anchanchatina marginata according to Orisawiyi (1989) is a high quality food rich in protein, low in fats and a good source of iron. Imebore and Ademoso (1988) also reported that snails have a protein content of $88.42 \%$ which compares with animal protein of $82.37 \%$ for pork and $92.75 \%$ for beef.

Marian et. al, (2004) reported on the nutritional compositions of green crabs (Carciunus maenas) to be protein $80.50 \%$, lipids $3-4.88 \%$, carotenoid $5.1-19.2 \%$ of crab meat. 
Anthony et. al., (1983) also reported that shellfishes are a good source of protein, low fat and macro- minerals and trace elements such as copper, iron, zinc and manganese. Anne De La Hunty in (1995) advised in her report that eating of shellfishes is part of healthier lifestyle. Tom Pickerel (2010) reported on the nutritional components of shellfishes as good source of Vitamin B2, niacin, iron, purines, sodium, vitamin C, zinc, magnesium and Omega -3 fatty acids. According to Bahy et. al., (2010), difference in nutritional values could be attributed to species, regions and environments, therefore snails like many shellfishes have been observed to contain high concentration of iron, calcium, magnesium and zinc. No wonder pregnant women have been reported by Adeyeye (1996) of high intake of snail haemolymph. The FAO (2001) has reported that subjects who eat Crustaceans and Molluscs have reduced levels of triglycerides and blood fats that cause clogging of arteries and this has been attributed to the omega-3 content of these shellfishes. According to Len in Hubpages (2010), Oysters are main source of zinc which is essential for maintenance of senses of taste and smell. Oyster also is a good source of tyrosine, an amino acid used by the brain to help regulate mood and adapt to stress. It is also an aphrodisiac as it contains an amino acid that riggers increase levels of sex hormones. The zinc content of oysters aids in the production of testosterones.

The abundance of freshwater snails in River Benue and its tributaries has been studied by Omudu and Iyough (2005). This is due to the availability of food, shelter and oviposition sites along the river water body. Most of the populations along the river catch these snails for food and as a substitute to animal protein which has gone beyond the reach of the common man. Despite the views of snails in West Africa as an intermediate host of pathogenic nematodes (Wosu, 2003), humans have continued to haunt for snails for food many generations due to its nutritional and medicinal values.

The aim of this work therefore is to study the nutritional composition of the freshwater snail Pila ampullacea which is common along the Lower River Benue and how it can be popularized and incorporated in the diets of the teaming population. This will go a long way to reduce malnutrition among the people and increase the economy of the area as they go fishing for snails and other aquatic animals.

\section{Materials and Methods.}

The snail (Pila ampullacea) was bought from fishermen in the Wadata fish market in Makurdi, capital of Benue State in Nigeria. The samples were washed and taken to the Biochemistry Department of the National Institute of Veterinary Research Vom, Plateau state, Nigeria.

The soft tissue which is the meat was separated from its shell through the use of drilling pin. This mass of tissue with the haemolymph was lyophilized and dehydrated in an oven at $60^{\circ} \mathrm{C}$ for $24 \mathrm{hrs}$ (Ebenso, 2003). The dried sample was ground into powder in an electric blender. 2grams of the samples were taken for analysis where the moisture, ash and protein, crude fiber were analyzed by the methods described by AOAC (1990). The protein was determined by the Micro-kjeldahl method. Fat content was determined by Bligh and Dyer method. The mineral content was determined by dissolving the ash obtained from the sample in standard flask with distilled de-ionized water. A few drops of concentrated hydrochloric acid were added. The mixture was warmed and evaporated on Bochy water bath and filtered using a filter paper. The aliquots were taken for estimates of calcium, phosphorus, iron, sodium and potassium following the methods of AOAC (1990).

\section{Results}

The proximate composition of the tissue of Pila ampullacea are as shown in Table I. The mean moisture content was $76.32 \% \pm 0.84$, the crude protein was $10.67 \% \pm 0.15 \%$, the lipid content was $0.06 \% \pm$ 0.02 , while the ash content was $5.54 \% \pm 0.11$ and the nitrogen free extract was $7.40 \% \pm 0.06$. The mineral compositions obtained from Pila ampullacea are as shown in Table 2. The mean calcium content was $128.35 \mathrm{mg} / 100 \mathrm{~g} \pm 0.35$, the iron content was $10.57 \mathrm{mg} / 100 \mathrm{~g} \pm 0.19$, sodium was $0.03 \mathrm{mg} / 100 \mathrm{~g} \pm 0.01$, phosphorus was $60.24 \mathrm{mg} / 100 \mathrm{~g} \pm 0.03$, and potassium was $70.40 \mathrm{mg} / 100 \mathrm{~g} \pm 0.51$ while magnesium was $30.45 \mathrm{mg} / 100 \mathrm{~g} \pm 0.51$.

Table 1: Mean Proximate Composition of Flesh of pila ampullaceal

\begin{tabular}{|l|c|}
\hline Parameters & \% Composition \\
\hline Moisture & $76.32 \pm 0.84$ \\
Crude Protein & $10.67 \pm 0.15$ \\
Crude Fibre & $0.03 \pm 0.01$ \\
Lipids & $0.06 \pm 0.02$ \\
Ash & $5.54 \pm 0.11$ \\
Nitrogen Free Extract & $7.40 \pm 0.15$
\end{tabular}




Table 2: Mineral Contents of Flesh of pila ampullaceal (mg/100g)
\begin{tabular}{|l|c|}
\hline Minerals & Mean Composition $(\mathrm{mg} / 100 \mathrm{~g})$ \\
\hline Calcium & $129.18 \pm 0.77$ \\
Potassium & $71.13 \pm 0.51$ \\
Phosphorus & $60.52 \pm 0.35$ \\
Iron & $10.90 \pm 0.19$ \\
Sodium & $0.04 \pm 0.01$ \\
Magnesium & $31.19 \pm 0.57$ \\
Zinc & $1.31 \pm 0.03$
\end{tabular}

\section{Discussion}

The results obtained from this study showed that Pila ampullacea an aquatic snail appears in the river between the months of May - September. The moisture content of $76.32 \% \pm 0.84$ obtained from the snail falls within the range of $73.67-99.20 \%$ that has been reported on snails by Wosu (2003) and Eneji et. al., (2008) although it was smaller than what has been reported for Pila globosa (85.5\%) and Whelk (66.17\%) found in Europe, Asia and Africa. These variations could be due to the effect of environment as reported by Osibona et. al., (2006).

The protein content of $10.40 \%$ of P. ampullacea is lower than that of fresh water fishes and the giant land snail Archchatina maginat, however it is still comparable to values obtained in other livestock (FAO 2001). Bender (1992) has responded that the amino acids in the protein of snail could be used to compliment the cereal sources of protein making good their relative deficiency of lysine. The crude fibre content of $0.01 \%$ falls within the range observed by Eneji et. al., (2008) of 0.50-1.50\% for land and water snails. It has been observed that the low crude fibre of $P$. ampullacea, an aquatic snail is due to swimming activity of the snails in water which is more strenuous than crawling on land. Thus aquatic snails are tougher than land snails (Eneji et. al., 2008).

The ash content of 5.84\% is similar to what was observed by Akinusi (1998) and Abwoa (1995). This value can be attributed to the fact that the aquatic snails absorb more minerals from the water as rivers serve as effluent to some industries whose chemical waste discharge into the water body may increase the absolute minerals in the water.

The lipid count of $0.09 \%$ is low compared to other species of animals (Judith and Jenny, 1987). This attest to the extensive use of snails for treatment of hypertension, and other related ailments (Adegbola, 1998). The low value is because aquatic snails require more energy for its physiological activities such as swimming which require more energy from lipids. This could be related to location and origin of the snails too (Abua, 1995 and Lee, 1994).

The nitrogen free extract value of $7.66 \%$ was observed for $P$. ampullacea which falls within the range observed by Eneji et. al., (2008) but it could depend on cooling time (Imeubore and Ademosum 1998). The ash content and subsequent qualities of the mineral components of $P$. ampullacea agrees with the work of Eneji et. al., (2008) who have observed that aquatic snails had higher mineral contents than land snails.

The phosphorus content of $60.58 \mathrm{mg} / 100 \mathrm{~g}$ is below that recorded for beef (156), liver (313), eggs (218) and milk (95) mg/100g (Fox and Cameron, 1980), therefore making snail not to be a good source of phosphorus. However, the calcium content of $129.0 \mathrm{mg} / 100 \mathrm{~g}$ observed for $P$. ampullacea was high when compared to values for beef 7, liver -6 , egg -54 and milk -120 . This lends credence to the richness of snail meat with calcium as observed by (Babalola and Akinsoyinu, 2009). Calcium is known to be involved in bone and teeth calcification, nerve function and blood clothing. Therefore $P$. ampullacea meat can be used as supplement in feeds for humans and other animals. Potassium content of $70.58 \%$ in the $P$. ampullacea is high which agrees with the work of Eneji et. al., (2008) who worked on some water snail species in Nigeria. Potassium is good for help in fluid balance and regulation of nerve impulse conduction, regular heart beat and cell metabolism therefore according to Fagbwano et. al., (2006), the consumption of snails will definitely increase the level of these major elements in the body. The iron content of $10.65 \mathrm{mg} / 100 \mathrm{~g}$ observed in this work falls within the range of $6.79-$ $11.0 \mathrm{mg} / 100 \mathrm{~g}$ obtained by Wosu, (2003). This element is important for red blood formation, therefore aquatic snail can be recommended for pregnant women and children. Magnesium content of P. ampullacea was found to be $30.89 \mathrm{mg} / 100 \mathrm{~g}$ which falls within the range found by Eneji et. al., (2008) for Nucella lapillus. The zinc content was found to be $1.21 \mathrm{mg} / 100 \mathrm{~g}$ which fell within the range observed by Eneji et. al., (2008) and Fagbuaro et. al., (2006) in other aquatic snail species.

These important minerals found in this study shows that snail is a good source of these minerals which are vital for healthy growth of the body, helping muscles, nerves and proper metabolism of body, therefore should be incorporated in the diets of man and its animals particularly the growing ones. 


\section{References.}

[1] Abuoa, F. (1995). Proximate analysis and mineral contents of two Giant African snails consumed in Ivory Coast. Tropical Science, England. 35: $220-222$.

[2] Adegbola, P. O. (1998). "Snail rearing". A seminal paper presented at the Forestry

[3] Forestry Research Institute of Nigeria, Ibadan. October $28^{\text {th }} 1998$.

[4] Adesehinwa, A. O. K. and Ogunmodede, B. K. (1995). "Swine Feeds and Practical

[5] Feed Composition Techniques". Paper presented at National Agricultural Extension and Research, Liason Service. National pig production workshop. National Research Institute, Moor Plantation, Ibadan. 3-5 ${ }^{\text {th }}$ April 1995

[6] Adeyeye, E. I. (1996). "Waste Yield, proximate and mineral composition of three different types of Land snails found in Nigeria". Int. J. food and Nutr., 47: 111-116.

[7] Akinnusi, O. (2002). Introduction to snails and snail farming. Triolas publishing company,

[8] Abeokuta, $70 \mathrm{pp}$.

[9] Anne de la Hunty, (1995). The COMA report on nutritional aspects of cardiovasculardisease: the scientific evidence, British Food journal, vol: $97 \quad$ (9) pp30-32.

[10] AOAC, (1995). Association for Official Analytical Chemist. Official Methods for Analysis, $15^{\text {th }} \quad$ Ed. Washington DC.

[11] Babalola, O. O. and Akinsoyinu, A. O. (2009). Proximate composition and mineral profile of snail meat from different breeds of land snails in Nigeria. Pakistan Journal of Nutrition, 8 (12): pp1842 - 1844.

[12] Bender, A. (1992). Meat and meat products in human Nutrition in developing Contries. FAO Food and Nutrition. FAO, Rome. $53 \mathrm{pp}$.

[13] Ebenso, I. E. (2003). Dietary calcium supplement for edible tropical land snail (Archachatina marginata) in Niger Delta, Nigeria. Livestock Research for rural development, vol 15:

[14] Eneji, C. A., Ogogo, A. U., Emmanuel- Ikpeme, C. A. and Okon, O. E.(2008). Nutritional assessment of some Nigerian land and water snail species. Ethiopian journal of Environmental studies and management. 1(2) 56-60.

[15] Fagbuaro, O., Oso, J. A., Edward, J. B. and Ogunleye, R. F. (2006). Nutritional status of four species of Giant land snails in Nigeria. Journal of Zhejiang University, $\quad$ Science B, 7 (9): 686 - 689.

[16] FAO (1998). Food and Agricultural Organization Annual Report. Rome, Italy. 32 -

[17] Fisheries Statistics of Nigeria (2007). Inland Fisheries $4^{\text {th }}$ Ed pp 49.

[18] Fox, B. A. and Cameron, A. G. (1980). Food Science, Chemical Approach. Hodder and Stoughton Educational, $3^{\text {rd }}$ Ed.

[19] Hodasi , J. K. M. (1982). Some Aspects of the Biology of Achatina - Achatinna (Linne). Journal of Molluscan Studies. 48 : 100 133.

[20] Idufueke, A. D. (1984). Nigerian move towards self- sufficiency in Animal protein production: Proceedings of the Nigerian Veterinary medical Association Annual conference, Lagos.

[21] Ihekoronye, A. I. and Ngoddy, P. O. (1995). Integrated Food Science and Technology for Tropics. MacMillan Pub. Ltd. London. 78pp.

[22] Judith, K and Jenny, M (1987). Proximate composition, energy, fatty acids, sodium and cholesterol content of finfish, shellfish, and other products. National Oceanographic and Atmospheric Administration (NOAA), Technical Report, US Department of Commerce.

[23] Lee M. K., Moon J. H. and Ryu H. S. (1994): "Nutrients Composition and Protein Quality of Giant Snail Product". Journal of Korean Society of Food and Nutrition.23; 453-458.

[24] Luzia L. A., Sampaio G. R., Castellucci C. M N. and Torres E. A. F. S. (2003). "The influence of season on the Lipid Profiles of Five Commercially Important Species of Brazilian Fish.” Food chemistry 83:93-97.

[25] Marian. N., Williams J., Brennan K. Chandrika L. and Shahidi F. (2004). "Composition Characteristics of Green Crab (Carcinus maenas).

[26] Okon B. I. (1987).’Utilization of Periwinkle Flesh by Broilers Fed Palm Kernel-based rations”. PhD Thesis, university of Ibadan,Nigeria.

[27] Omudu E. A. and Iyough Achagh (2005). "Ecological Studies of the Gastropod Fauna of Some Minor Tributeries of River. Research Intertional. 2(2): 306-310. 